\title{
APLIKASI PERAMALAN PENJUALAN OBAT MENGGUNAKAN METODE LEAST SQUAREDI RUMAH SAKIT BHAYANGKARA
}

\author{
Medyantiwi Rahmawita, Ilham Fazri ${ }^{2}$ \\ ${ }^{1,2}$ Program Studi Sistem Informasi Fakultas Sains dan Teknologi \\ Universitas Islam Negeri Sultan Syarif Kasim Riau \\ Jalan HR. Soebrantas KM 15 No. 155 Pekanbaru - Riau \\ E-mail:Ilhamfazri05@gmail.com ${ }^{1}, @$ uin-suska.ac.id ${ }^{2}$
}

\begin{abstract}
ABSTRAK
Rumah Sakit Bhayangkara merupakan salah satu instansi kesehatan negeri yang sedang menghadapi persaingan dalam tuntutan akan pelayanan kesehatan yang baik dan bermutu.Pengeloaan data penjualan dan manajemen stok obat menggunakan sistem secara manual menjadi suatu masalah yang memerlukan sebuah sistem aplikasi peramalan obat yang dapat mengelola data penjualan.Sebagai Instansi kesehatan negeri, Rumah Sakit Bhayangkara perlu mengadakan pembuatan sistem aplikasi peramalan obat-obatan untuk dapat mengelola stok obat dan data penjualan lebih baik.Tujuan penelitian ini adalah meramalkan penjualan obat-obatan di Rumah Sakit Bhayangkara dengan menggunakan metode least square berdasarkan data penjualan sebelumnya dan meringankan petugas dalam pengolaan data persediaan obat.Penelitian ini menggunakan metode least square dengan sampling sebanyak 120 item dan menggunakan Mean Absolute Percentege Error (MAPE) untuk perhitungan error.Hasil peramalan menggunakan metode least square mempunyai error (tingkat kesalahan) yang diukur dengan MAPE adalah 3\%. Hal ini menunjukkan metode least square sangat bagus dalam meramalkan stok obat masa yang akan datang. Hasil akhir dari penelitian ini diharapkan dapat membantu proses perhitungan peramalan obat masa datang secara mudah, memperkecil kesalahan, dan menghasilkan ramalan yang akurat dan cepat.
\end{abstract}

Kata Kunci:Metode Least Square, MetodeMAPE, Peramalan

\section{A. PENDAhuluan}

Rumah Sakit Bhayangkara merupakan salah satu industri kesehatan negeri yang sedang menghadapi tuntutan akan pelayanan kesehatan yang bermutu upaya menghadapi persaingan. Pengaruh ketersediaan obat-obatan merupakan patokan penting dalam industri kesehatan agar tetap produktif[1].

Selama ini pengeloaan data penjualan dan manajemen stok obat menggunakan sistem secara manual.Jadi, sistem tersebut memerlukan banyak buku untuk pencatatan penjualan, juga sering mengakibatkan lamanya perekapan data untuk pasien berobat jalan/inap, dan bahkan ada juga data penjualan yang hilang.Sedangkan untuk pembelian obat itu dilakukan 1 kali sebulan, dan pembeliannya memesan langsung ke distributor PBF (Pedagang Besar Farmasi) melalui telephone dan sales.Tetapi terkadang distribur PBF mengalami kekosongan stok obat dalam waktu relatife lama, oleh karna itu permasalahan tersebut membuat rumah sakit bhayangkara mengalami kekosongan stok obat yang relatife lama, dan juga mengalami laporan laporan yang tidak valid[2].

Oleh karena itu untuk mendapatkan sistem informasi manajemen pengolahan data yang bisa diakses dengan lebih mudah serta mampu menghasilkan laporan-laporan yang dibutuhkan, serta mendapatkan suatu keputusan yang akurat mengenai stok obat pada rumah sakit bhayangkara, maka diperlukan metode least square yang sangat berguna dalam meramalkan data periode sebelumnya untuk menghasilkan prediksi stok obat dimasa yang akan datang. Dengan begitu diharapkan sistem ini dapat menghasilkan peramalan obat-obatan yang mampu menutupi kekurangan-kekurangan yang ada selama ini.

Berdasarkan latar belakang masalah diatas, maka penulis bermaksud melakukan penelitian tugas akhir dengan judul "Aplikasi Peramalan Penjualan Obat Menggunakan Metode Least Square (Studi Kasus Rumah Sakit Bhayangkara)".

\section{B. LANDASAN TEORI \\ B.1 Metode Least Square (Kuadrat Terkecil)}

Metode Least Square merupakan salah satu metode berupa data deret berkala atau time series, yang mana dibutuhkan data-data penjualan dimasa lampau untuk melakukan peramalan penjualan dimasa mendatang sehingga dapat ditentukan hasilnya. Least Square adalah metode peramalan yang digunakan untuk melihat trend dari data deret waktu menurut[3].Persamaan 1 merupakan persamaan metode Least Square.

$Y=a+(1)$

Keterangan:

Y : Jumlah Penjualan

a dan b : Koefisien

$\mathrm{x} / \mathrm{t}$ : waktu tertentu dalam bentuk kode 
Dalam menentukan nilai $\mathrm{x} / \mathrm{t}$ seringkali digunakan teknik alternatif dengan memberikan skor atau kode. Dalam hal ini dilakukan pembagian data menjadi dua kelompok, yaitu:

a. Data genap, maka skor nilai t nya: ...,-5, $-3,-1,1,3,5, \ldots$

b. Data ganjil, maka skor nilai t nya: ...,$3,-2,-1,0,1,2,3, \ldots$

Kemudian untuk mengetahui koefisien a dan $b$ dicari dengan persamaan 2 dan 3 .

$\mathrm{a}=\frac{\boldsymbol{\Sigma} \mathbf{Y}}{\mathbf{N}}$
$\mathrm{b}=\frac{\boldsymbol{\Sigma} \mathbf{X Y}}{\boldsymbol{\Sigma} \mathrm{X}^{2}}$

\section{B.2 Basisdata}

Basisdata adalah kumpulan data (elementer) yang secara logika berkaitan dalam merepresentasikan fenomena/fakta secara terstruktur dalam domain tertentu untuk mendukung aplikasi pada sistem tertentu.Basisdata adalah kumpulan data yang saling berhubungan yang merefleksikan fakta-fakta yang terdapat di organisasi.Basisdata mendeskripsikan state organisasi/perusahaan/sistem. Saat satu kejadian muncul di dunia nyata mengubah state organisasi/perusahaan/sistem maka satu perubahan pun harus dilakukan terhadap data yang disimpan di basisdata. Basisdata merupakan komponen utama sistem informasi karena semua informasi untuk pengambilan keputusan berasal dari data di basisdata.Pengelolaan basisdata yang buruk dapatmengakibatkan ketidaktersediaan data penting yang digunakan untuk menghasilkan informasi yang diperlukan dalam pengambilan keputusan [4]

\section{B.3 MySQL}

MySQL adalah program database server yang mampumenerima dan mengirimkan datanya dengan sangat cepat, multi user serta menggunakan perintah standa SQL (Structured Query Language).

MySQL merupakan sebuah database server yang free, artinya kita bebas menggunakan database ini untuk keperluan pribadi atau usaha tanpa harus membeli atau membayar lisensinya.MySQL pertama kali dirintis oleh seorang programmer database bernama Michael Widenius. Anda dapat menghubunginya melalui email dengan alamat monty@analytikerna.se.Selain sebagai database server, MySQL juga merupakan program yang dapat mengakses suatu database MySQL yang berposisi sebagai server.Pada saat itu berarti program kita berposisi sebagai Client.Jadi MySQL adalah sebuah database yang dapat digunakan baik sebagai Client maupun Server [5]

MySQL merupakan software sistem manajemen database (Database Management System - DBMS) yang sangat popular di kalangan pemrogram webb, terutama di lingkungan Linux dengan menggunakan scrip PHP dan Perl[6].
MysQL mendapatkan penghargaan sebagai database terbaik untuk server Linux Magazine pada tahun 2002 dan 2001, dan sebagai database favorit pada tahun 2000 [7].

\section{B.4 PHP}

Kelahiran PHP bermula saat Rasmus Lerdorf membuat sejumlah skrip Perl yang dapat mengamati siapa saja yang melihat-lihat daftar riwayat hidupnya, yaitu tahun 1994. Tahun 1995, Rasmus menciptakan PHP/FI Versi 2, di manaVersi tersebut dapat menempelkan kode terstruktur dalam tag HTML dan juga PHP dapat berkomunikasi dengan database[8].

PHP sebagai alternative lain memberikan solusi sangat murah (karena gratis digunakan) dan dapat berjalan diberbagai jenis platform. PHP (atau resminya PHP: Hypertext Preprosessor) adalah skrip bersifat server-side yang ditambahkan ke dalam HTML. PHP sendiri merupakan singkatan dari Personal Home Page Tools. Skrip ini akan membuat suatu aplikasi dapat diintegrasikan kedalam HTML sehingga suatu halaman web tidak lagi bersifat statis, namun menjadi bersifat dinamis. Sifat server side berarti pengerjaan skrip dilakukan deserver, baru kemudian hasilnya di kirimkan ke browser[9].

\section{B.5 Metode SDLC (System Development Life Cycle)}

Model Waterfall merupakan salah satu model pengembangan perangkat lunak yang ada di dalam model SDLC (Sequencial Development Life Cycle) [10]. mengemukakan bahwa "SDLC atau Software Development Life Cycle atau sering disebut juga System Development Life Cycle adalah proses mengembangkan atau mengubah suatu sistem perangkat lunak dengan menggunakan model-model dan metodologi yang digunakan orang untuk mengembangkan sistem-sistem perangkat lunak sebelumnya, berdasarkan best practice atau cara-cara yang sudah teruji baik." waterfall sering juga disebut model sekuensi linear atau alur hidup klasik.Pengembangan sistem dikerjakan secara terurut mulai dari analisis, desain, pengkodean, pengujian dan tahap pendukung[11][12].

Adapun penjelasan dari metode ini adalah sebagai berikut :

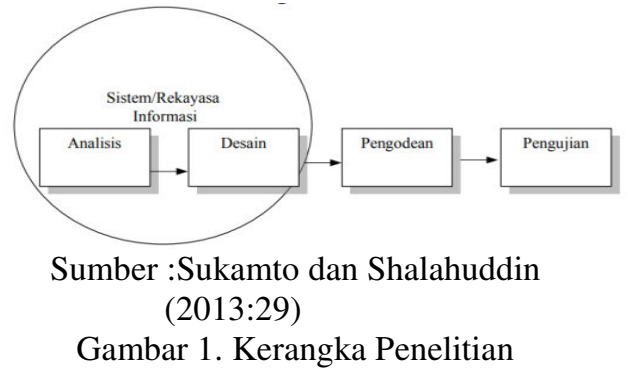


1. Analisis

Dalam tahap ini penulis mulai menganalisa apa saja kebutuhan dari system, mulai dari kebutuhan fungsional system maupun kebutuhan non fungsional dari sistem

2. Desain

Tahap desain merupakan tahapan lanjut dari tahap analisis dimana dalam tahap ini disajikan desain desain dari aplikasi seperti desain antar muka, dan desain data base yang akan diterapkan kedalam system Informasi Akademik yang akan dibuat

3. Pengkodean

Pada tahap ini penulis menerapkan desai data base serta desain antar muka kedalam bahasa pemrograman, dimana bahasa pemrograman yang dipakai adalah menggunakan bahasa PHP untuk website

4. Pengujian

Tahap uji merupakan tahap akhir dalam metode waterfall dimana dalam tahap pengujian ini digunakan teknik pengujian blackbox testing

\section{B.6 Sejarah Rumah Sakit Bhayangkari}

Untuk legalitas penyelenggaraan Rumah Sakit maka departemen kesehatan RepublikIndonesia memberikan izin penyelenggaraan berdasarkan keputusan Menteri Tahun 1969 Seksi Kesehatan Komdak IVRiau yang berlokasi di Jalan Teratai. Sesuai dengan perkembangan zaman, maka pada tahun 1975 Rumah Sakit KOMDAK IV Riau menjadi Rumah Sakit Bhayangkara Pekanbaru TK.IV, maka pada tanggal 12 bulan Desember tahun 2013 Rumah Sakit Bhayangkara Pekanbaru Polda ditetapkan sebagai Rumah Sakit UmumKelas C [7].

Kesehatan Republik Indonesia Nomor: YM.0204.3.1.1080 tentang pemberian izin penyelenggaraan kepada markas besar Kepolisian Negara Republik Indonesia Jl. Trunojoyo No.3 Kebayoran Baru Jakarta Selatan DKI Jakarta. Untuk menyelenggarakan Rumah Sakit Bhayangkara Pekanbaru Provinsi Riau dan telah diperpanjang melalui Surat Keputusan Dinas Kesehatan Kota Nomor: 710/441/IV/2013 tanggal 5 April 2013 tentang pemberian izin Operasional Rumah Sakit Bhayangkara Pekanbaru.

Untuk meningkatkan mutu Rumah Sakit Dalam memberikan Pelayanan Kesehatan terhadap Anggota Polri,PNS Polri, dan Keluarga serta masyarakat secara umum,dan adanya program dari Departemen Kesehatan RI untuk mewajibkan setiap Rumah Sakit menerapkan Standar Pelayanan Rumah Sakit maka Rumah Sakit Bhayangkara
Pekanbaru berusaha untuk memenuhinya dan berdasarkan Keputusan Menteri Kesehatan RI Nomor: YM.01.10/III/4685/09 Tanggal 12 November 2009 telah ditetapkan status Akreditasi penuh tingkat dasar kepada Rumah Sakit Bhayangkara Pekanbaru.

\section{METODOLOGI PENELITIAN}

Penelitian ini merupakan penelitian deskriptif dengan menggunakan metode survey untuk dapat memberikan gambaran terhadap terhadap objek yang diteliti.Wawancara dan pengamatan langsung dengan pihak yang terkait. Data Sampel dalam penelitian ini adalah data transaksi penjualan obat di Rumah Sakit Bhayangkari, yang dalam penelitian ini data langsung diambil dari Rumah Sakit Bhayangkari dan merupakan data rekapitulasi laporan bulanan tahun 2016.

\section{ANALISA DAN PERANCANGAN}

\section{D.1 Analisa Sistem}

Analisa sistem didefenisikan sebagai penguraian suatu sistem informasi yang utuh kedalam komponen-komponen yang bertujuan untuk mengidentifikasi, mengetahui dan memahami serta melakukan proses evaluasi yang baik atas permasalahan yang terjadi. Kegiatan analisa sistem dilakukan untuk mendapatkan jarak antara realita penggunaan sistem lama dan keinginan perusahaan untuk mencapai target bisnis perusahaan dengan menerapkan sistem baru. Setelah hal tersebut telah didapatkan maka akan diuraikan bagaimana perancangan sistem usulan yang diharapkan memenuhi kebutuhan para pengguna sistem.

\section{D.2 Analisis Sistem Yang Sedang Berjalan}

Berikut akan diuraikan secara umum sistem yang sedang berjalan pada RS.Bhayangkara:

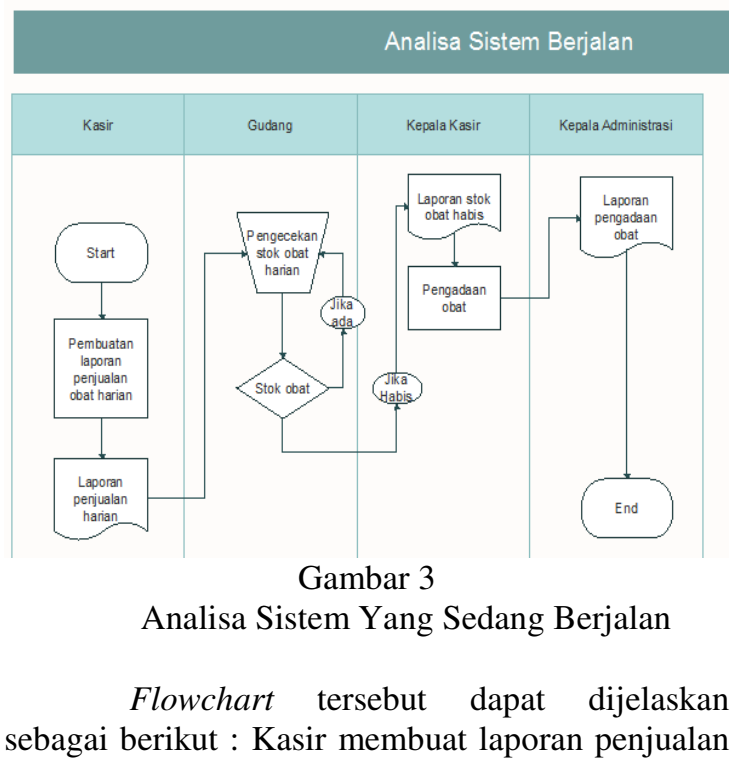


obat harian dan diberi ke gudang untuk pengecekan stok obat pada hari itu, kemudian jika stok obat habis maka pihak gudang membuat laporan stok obat yang habis untuk diberikan kepada kepala kasir, kemudian kepala kasir melihat dan membuat laporan pengadaan obat menggunakan instuisi, setelah itu laporan dikirim kepala kepala administrasi untuk pemesanan stok obat.

Pada pihak kasir dan gudang merasa kesulitan dalam pembuatan laporan penjualan dan pengecekan stok obat dikarenakan dengan cara manual, oleh sebab itu mereka sering kali merangkap pembuatan laporan dan pengecekan stok obatnya $2 \mathrm{x}$ dalam 2 minggu. Hal tersebut membuat apotik RS.Bhayangkara sering kehabisan stok obat yang merugikan pihak RS.Bhayangkara terhadap pelayanannya ke pasien.

\section{D.3 Analisa Sistem Yang Akan Dibangun}

Pada tahap analisa sistem yang sedang berjalan dapat disimpulkan bahwa sistem yang ada memiliki beberapa permasalahan dan kelemahan yang perlu dilakukan perbaikan dan perlu dibangun sistem yang efisien dengan aplikasi peramalan stok obat ini.

\section{D.4 Perancangan Sistem Yang Diusulkan}

Perancangan sistem usulan akan menggunakan metode SDLC. Kasir dan gudang RS.Bhayangkara membutuhkan aplikasi peramalan stok obat dan juga aplikasi pembuatan laporan penjualan, untuk mempermudah mereka dalam pembuatan laporan dan meramal stok obatnya. Dengan demikian penentuan target dapat lebih dipertanggung jawabkan dan lebih berdasar. Terdapat tiga entitas, yaitu:

1. Bagian Kasir/penjualan : adalah pihak yang memasukkan data penjualan, dan data obat.

2. Bagian Gudang/pembelian : adalah pihak yang memasukkan data pembelian, dan data obat, beserta ramalannya.

3. Kepala Bagian Penjualan : adalah pihak yang dapat melihat laporannya.

Rekomendasi peramalan yang akan digunakan adalah meggunakan metode Least Square sebagai dasar peramalan. Least Square merupakan cara yang lebih umum dan lebih baik untuk menentukan nilai Trend dibandingkan dengan metode-metode yang lainnya (Budiasih Yanti, 2012). Diagram Alir sistem peramalan dengan metode Least Square ditunjukkan pada Gambar 4.2.

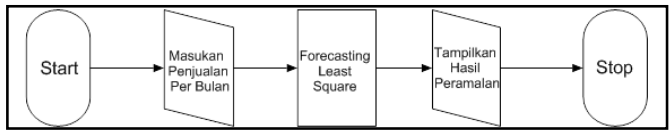

Gambar 4. Diagram Alir Analisa Sistem.

Penjelasan Gambar 4. : Tahap analisis yang dimulai dengan memasukkan data penjualan tiap bulan. Kemudian sistem akan memulai peramalan penjualan ke bulan berikutnya menggunakan metode Least Square (Kuadrat Terkecil). Setelah proses peramalan selesai maka sistem akan menampilkan hasil peramalan untuk bulan berikutnya.

\section{D.5 Representasi Model}

Data penjualan merupakan data yang wajib ada dalam proses peramalan atau suatu prediksi, oleh karena itu dalam sistem peramalan ini akan menggunakan data aktual penjualan obat 12 bulan yang lalu pada Rumah Sakit Bhayangkara. Berikut adalah representasi data aktual penjualan obat dan contoh perhitungan penerapan peramalan menggunakan metode Least Square. Sumber data yang akan digunakan adalah total dari penjualan tiap bulan dari periode Januari - Desember 2016. Tabel 1 dibawah ini akan menampilkan jumlah data penjualan obat tiap bulan.

Tabel .1 Data Penjualan Obat Tahun 2016

\begin{tabular}{cccccc}
\hline $\begin{array}{c}\text { Nama } \\
\text { Obat }\end{array}$ & Molexflu & $\begin{array}{c}\text { Om } \\
\text { Enrizol } \\
\mathbf{5 0 0 ~} \mathbf{~ m g}\end{array}$ & Cetrizine & Anaflu & Paracettaamol \\
\hline Jan & 186 & 75 & 154 & 100 & 20 \\
Feb & 183 & 76 & 163 & 94 & 25 \\
Mar & 180 & 77 & 150 & 98 & 30 \\
Apr & 180 & 71 & 171 & 120 & 15 \\
Mei & 188 & 76 & 165 & 133 & 40 \\
Jun & 187 & 75 & 167 & 112 & 22 \\
Jul & 181 & 75 & 165 & 87 & 20 \\
Agt & 180 & 73 & 161 & 99 & 33 \\
Sep & 182 & 78 & 151 & 103 & 17 \\
Okt & 180 & 74 & 165 & 128 & 21 \\
Nov & 185 & 74 & 170 & 105 & 33 \\
Des & 188 & 76 & 188 & 121 & 24 \\
\hline & & & & & \\
\hline
\end{tabular}

Proses peramalan menggunakan metode Least Square dimulai dengan menentukan jumlah $\mathrm{N}$ (jumlah periode/tahun) dan banyaknya pasangan data yang akan digunakan dalam peramalan sebagai periode dasar. Kemudian akan ditentukan nilai a (besar nilai Trend). Selanjutnya sistem akan menghitung nilai $\mathrm{b}$ (perubahan nilai Trend) terhadap $\mathrm{X}$ (periode waktu). Hasil perhitungan tersebut akan digunakan untuk menentukan nilai $\mathrm{Y}$ (taksiran) atau hasil peramalan pada periode yang diramalkan tingkat penjualannya.

Keterangan simbol untuk perhitungan metode Least Square (kuadrat terkecil, sebagai berikut :
Y : Penjualan
$\mathrm{N}$ :jumlah/banyaknya pasangan data
a :Koefisien
b :Koefisien 
kode jurnal ilmiah

X :Waktu tertentu dalam bentuk

$$
\begin{aligned}
& \boldsymbol{\Sigma} X \quad \text { :jumlah nilai } Y \\
& \boldsymbol{\Sigma} X^{2} \text { :jumlah nilai } X^{2}
\end{aligned}
$$

$\Sigma X Y$ :jumlah nilai XY

Berikut adalah perbandingan grafik untuk data aktual selama 12 bulan dari masing-masing item obat, diantaranya sebagai berikut :

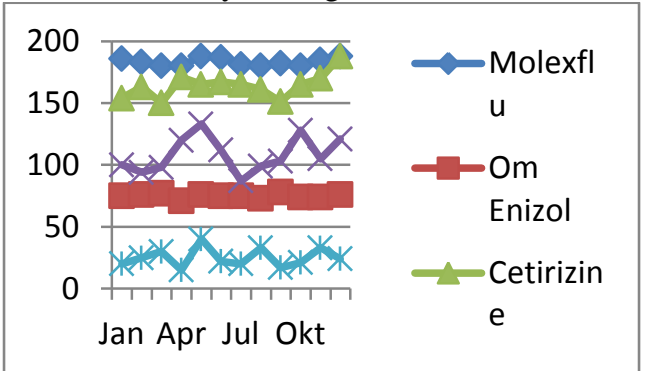

Gambar 5 Grafik perbandingan data aktual Cetirizine

Berikut adalah algoritma perhitungan peramalan menggunakan metode Least Square seperti yang terlihat pada Gambar 6 .

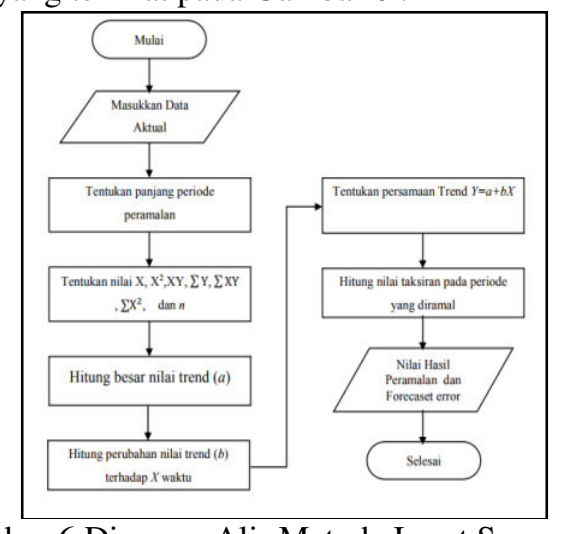

Gambar 6 Diagram Alir Metode Least Square

Keterangan Diagram Alir Metode Least Square :

1. Masukkan data aktual penjualan.

2. Menentukan jumlah n (jumlah periode/bulan) dan banyaknya pasangan data yang digunakan dalam peramalan sebagai periode dasar.

3. Mencari nilai $\mathrm{X}, \mathrm{X}^{2}, \mathrm{XY}, \boldsymbol{\Sigma} \mathrm{Y}, \boldsymbol{\Sigma} \mathrm{XY}, \boldsymbol{\Sigma} \mathrm{X}^{2}$ untuk dasar mencari Trend.

4. Mencari nilai a (besar nilai Trend)

5. Menghitung nilai $b$ (perubahan nilai Trend) terhadap X (waktu).

6. Menentukan persamaan Trend yang akan digunakan $(\mathrm{Y}=\mathrm{a}+\mathrm{bX})$

Contoh perhitungan :

Tentukan jumlah data yang akan digunakan. Karena data yang digunakan berjumlah 12 periode dan habis dibagi dua yaitu genap maka dipakai skala $\mathrm{x}=1 / 2$ tahun. Maka periode dasar diletakkan pada tahun yang diantara periode Juni dan Juli 2016. Pada tabel dibawah dijelaskan Periode $=$ Bulan Penjualan, $\mathrm{Y}=$ Jumlah penjualan perbulan, $\mathrm{X}=$ Periode waktu, $\mathrm{X}^{2}=$ Kuadrat periode waktu, $\mathrm{XY}=$ hasil kali antara periode waktu dengan penjualan perbulan.

Tabel 2. Perhitungan Forecast Cetirizine

\begin{tabular}{llllll}
\hline $\mathbf{N}$ & Periode & Cetrizine & $\mathbf{X}$ & $\mathbf{X}^{\mathbf{2}}$ & $\mathbf{X Y}$ \\
\hline 1 & Januari & 154 & -11 & 121 & -1694 \\
2 & Februari & 163 & -9 & 81 & -1467 \\
3 & Maret & 150 & -7 & 49 & -1050 \\
4 & April & 171 & -5 & 25 & -855 \\
5 & Mei & 165 & -3 & 9 & -495 \\
6 & Juni & 167 & -1 & 1 & -167 \\
7 & Juli & 165 & 1 & 1 & 165 \\
8 & Agustus & 161 & 3 & 9 & 483 \\
9 & September & 151 & 5 & 25 & 755 \\
10 & Oktober & 165 & 7 & 49 & 1155 \\
11 & November & 170 & 9 & 81 & 1530 \\
12 & Desember & 188 & 11 & 121 & 2068 \\
\hline $\mathrm{N}=12$ & & 1970 & 0 & 571 & 428 \\
\hline
\end{tabular}

1. Didapat jumlah dari masing-masing variabel yang terdapat pada tabel 4.2 adalah sebagai berikut :

$\boldsymbol{\Sigma Y}=$ Jumlah keseluruhan periode penjualan obat (Cetirizine)

$\boldsymbol{\Sigma} \mathrm{X}^{2}=$ Jumlah kuadrat $\mathrm{X}$

$\boldsymbol{\Sigma X Y}=$ Jumlah perkalian antara waktu dan penjualan

$\Sigma Y \quad=1970$

$\Sigma X^{2}=572$

$\Sigma X Y=428$

$\mathrm{N} \quad=12$ (banyaknya baris)

2. Perhitungan dengan metode Least Square :

$\mathrm{Y}=\mathrm{a}+\mathrm{bX}$

$\mathrm{Y}=$ nilai trend pada periode tertentu

$\mathrm{a} \quad=$ intersep yaitu besarnya nilai $\mathrm{Y}$ bila nilai

$\mathrm{X}=0$

$\mathrm{b}=$ slope garis trend, yaitu perubahan variabel Y untuk setiap perubahan satu unit variabel $\mathrm{X}$

$\mathrm{X}$ =periode waktu

Hitung (a) dari tiap jenis obat :

$$
\begin{array}{ll}
a & =\Sigma Y / N \\
a & =1970 / 12=164,16
\end{array}
$$

Hitung slope garis trend (b) dari masingmasing jenis obat:

$$
b=\boldsymbol{\Sigma} \mathrm{XY} / \boldsymbol{\Sigma} \mathrm{X}^{2}=428 / 572=0,74
$$

Dari perhitungan diperoleh persamaan Least Square sesuai dengan persamaan rumus (2.4) sebagai berikut :

$$
\mathrm{Y}=164,16+(0,74) \mathrm{X}
$$

3. Dari persamaan di atas maka didapatkan taksiran penjualan untuk periode Januari 2017 sebagai berikut : 


$$
\begin{aligned}
\mathrm{Y}=164 & , 16+(0,74) \mathrm{X} \\
& =164,16+(0,74)(13) \\
& =164,16+9,62 \\
& =173,78
\end{aligned}
$$

Jadi banyaknya penjualan obat cetirizine periode januari 2017 diperkirakan sebanyak 173 item obat.

Dari persamaan di atas selanjutnya kita dapat memasukkan nilai trend untuk masingmasing periode seperti yang di tunjukkan pada tabel 3 dibawah ini.

Tabel 3 Perhitungan Forecast Cetirizine beserta hasil perhitungan Trend masing-masing periode

\begin{tabular}{lllllll}
\multicolumn{6}{c}{ hasil perhitungan Trend masing-masing periode } \\
\hline $\mathbf{N}$ & Periode & Cetrizine & $\mathbf{X}$ & $\mathbf{X}^{\mathbf{2}}$ & $\mathbf{X Y}$ & Trend \\
\hline 1 & Januari & 154 & -11 & 121 & -1694 & 156,02 \\
2 & Februari & 163 & -9 & 81 & -1467 & 157,5 \\
3 & Maret & 150 & -7 & 49 & -1050 & 158,98 \\
4 & April & 171 & -5 & 25 & -855 & 160,46 \\
5 & Mei & 165 & -3 & 9 & -495 & 161,94 \\
6 & Juni & 167 & -1 & 1 & -167 & 163,42 \\
7 & Juli & 165 & 1 & 1 & 165 & 164,9 \\
8 & Agustus & 161 & 3 & 9 & 483 & 166,38 \\
9 & September & 151 & 5 & 25 & 755 & 167,86 \\
10 & Oktober & 165 & 7 & 49 & 1155 & 169,34 \\
11 & November & 170 & 9 & 81 & 1530 & 170,82 \\
12 & Desember & 188 & 11 & 121 & 2068 & 172,3 \\
\hline $\mathrm{N}=12$ & & 1970 & 0 & 571 & 428 & 1969,62 \\
\hline
\end{tabular}

Sebagai salah satu contoh perhitungan nilai Trend diambil dari data tahun 2016 sebagaimana yang telah diberi warna kuning pada Tabel 4.3 :

Trend bulan Juli $(\mathrm{C})=(\boldsymbol{\Sigma} \mathrm{Y} / \mathrm{N})+\left(\left(\boldsymbol{\Sigma} \mathrm{XY} / \boldsymbol{\Sigma} \mathrm{X}^{2}\right) *(\mathrm{X})\right.$ $=(1970 / 12)+((428 / 572) *(1)$

$$
=(164,16)+(0,74) *(1)
$$$$
=164,16+(0,74)
$$

$$
=164.9
$$

\section{D.6 Forecast Error}

Terdapat beberapa metode untuk menghitung kesalahan / mengevaluasi hasil peramalan.Salah satu metode untuk mengevaluasi metode peramalan menggunakan jumlah dari kesalahan-kesalahan yang absolut. Mean Absolute Deviation (MAD) mengukur ketepatan ramalan dengan merata-rata kesalahan dugaan (nilai absolut masing-masing kesalahan). MAD paling berguna ketika orang yang menganalisis ingin mengukur kesalahan ramalan dalam unit yang sama dengan deret asli.

Data aktual adalah data asli penjualan $(Y)$, Penjualan Ramalan (Trend ) adalah hasil dari persamaan Least Square, Selisih (Error) diperoleh dari Penjualan aktual dikurangi hasil ramalan penjualan, $|\mathrm{Y}-\hat{\mathrm{Y}}|$ diperoleh dari selisih (Error) yang dimutlakkan untuk menghilangkan nilai (-) dalam angka.

Dari persamaan Least Square diatas diperoleh hasil perhitungan seperti yang terlihat pada tabel 4.4 di bawah ini.

Tabel 4 Forecast Error Cetirizine

\begin{tabular}{lllllll}
\hline $\mathbf{N}$ & Periode & Cetrizine & $\mathbf{X}$ & Trend & Eror & (Y-Trend) \\
\hline 1 & Januari & 154 & -11 & 156,02 & 121 & -1694 \\
2 & Februari & 163 & -9 & 157,5 & 81 & -1467 \\
3 & Maret & 150 & -7 & 158,98 & 49 & -1050 \\
4 & April & 171 & -5 & 160,46 & 25 & -855
\end{tabular}

\begin{tabular}{lllllll}
5 & Mei & 165 & -3 & 161,94 & 9 & -495 \\
6 & Juni & 167 & -1 & 163,42 & 1 & -167 \\
7 & Juli & 165 & 1 & 164,9 & 1 & 165 \\
8 & Agustus & 161 & 3 & 166,38 & 9 & 483 \\
9 & September & 151 & 5 & 167,86 & 25 & 755 \\
10 & Oktober & 165 & 7 & 169,34 & 49 & 1155 \\
11 & November & 170 & 9 & 170,82 & 81 & 1530 \\
12 & Desember & 188 & 11 & 172,3 & 121 & 2068 \\
\hline $\mathrm{N}=12$ & & 1970 & 0 & 1969,62 & & 76,06 \\
\hline
\end{tabular}

Contoh perhitungan nilai error diambil dari data uji pada tahun 2016, sebagaimana telah diberikan warna kuning pada Tabel diatas :

Error bulan januari $2016 \mathrm{C}=\mathrm{Y}-$ Trend

$$
=154-156,02
$$
$=2,02$

Dari tabel di atas didapatkan nilai MAD sebagai berikut :

$=76,06 / 12$

$\operatorname{MAD}($ Cetirizine $)=\frac{1}{\mathrm{~N}} \Sigma \mid \mathrm{Y}-$ Trend $\mid$

$=6,33$

Dari perhitungan di atas diperoleh kesalahan setiap peramalan per periode pada Cetirizine.

Tabel .5 Menghitung kesalahan prediksi menggunakan MAPE Cetirizine.

\begin{tabular}{lllllll}
\hline $\mathbf{N}$ & Periode & Cetrizine & $\mathbf{X}$ & Eror & (Y-Trend) & MAPE \\
\hline 1 & Januari & 154 & -11 & 121 & -1694 & 0,013 \\
2 & Februari & 163 & -9 & 81 & -1467 & 0,033 \\
3 & Maret & 150 & -7 & 49 & -1050 & 0,059 \\
4 & April & 171 & -5 & 25 & -855 & 0,061 \\
5 & Mei & 165 & -3 & 9 & -495 & 0,018 \\
6 & Juni & 167 & -1 & 1 & -167 & 0,021 \\
7 & Juli & 165 & 1 & 1 & 165 & 0,0006 \\
8 & Agustus & 161 & 3 & 9 & 483 & 0,033 \\
9 & September & 151 & 5 & 25 & 755 & 0,111 \\
10 & Oktober & 165 & 7 & 49 & 1155 & 0,026 \\
11 & November & 170 & 9 & 81 & 1530 & 0,004 \\
12 & Desember & 188 & 11 & 121 & 2068 & 0,079 \\
\hline $\mathrm{N}=12$ & & 1970 & 0 & 1969,62 & 76,06 & 0,4586 \\
\hline
\end{tabular}

sebagai berikut :

MAPE $($ Cetirizine $)=\mathbf{1 0 0} / \boldsymbol{n} \sum \boldsymbol{n t}=\mathbf{1}|\boldsymbol{Y} \boldsymbol{t}-\boldsymbol{Y t}| / \boldsymbol{Y t}$

$=0,459 / 12 \times 100$

$=0,038 \times 100$

$=3 \%$

\section{D.7 Analisa Kebutuhan}

Fungsional Dari gambaran umum sistem tersebut, dapat diketahui kebutuhan-kebutuhan fungsional untuk aplikasi peramalan penjualan obat, antara lain :

1. Sistem dapat melakukan validasi login berdasarkan hak akses user.

2. Sistem dapat melakukan input data penjualan obat.

3. Sistem dapat melakukan peramalan tingkat penjualan obat periode berikutnya berdasarkan data penjualan periode sebelumnya yang telah tersimpan dalam database menggunakan metode Least Square. 


\section{E. IMPLEMENTASI DAN PENGUJIAN \\ E.1 Implementasi Basis Data}

\section{Database SIRO}

Database merupakan tempat penyimpanan data, data sistem ini terdiri dari 7 field struktur tabel yaitu detail_pembelian, detail_penjualan, obat, pembelian, penjualan, tampung, user. Tampilan tabel sistem informasi ramalan obat rumah sakit bhayangkara ini dapat dilihat pada Gambar 5.1.

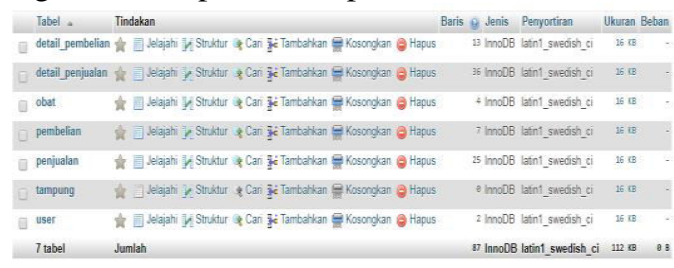

Gambar 6. Tampilan PHPMyAdmin Untuk

\section{Database SIRO}

\section{E.2 Hasil Implementasi Sistem}

1. Halaman Login

Tampilan depan dapat dilihat pada Gambar 5.1

\section{LOG IN}

a Sistem Informasi

Gambar 7 Tampilan Depan

2. Halaman Memilih Cetak Barcode

Tampilan memilih data obat yang ingin kita cetak barcode dapat dilihat pada Gambar 5.2

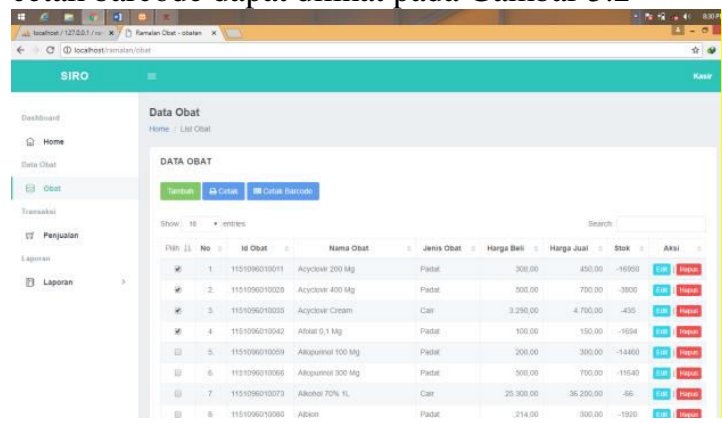

Gambar 8 Tampilan Pilih Data Obat Untuk di Cetak Barcode

3. Halaman Cetak Barcode

Tampilan cetak barcode yang telah kita pilih dapat dilihat pada Gambar 8

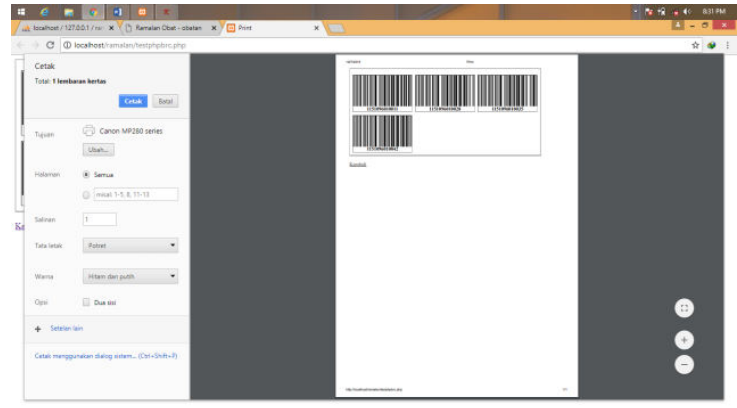

Gambar 9 Tampilan Cetak Barcode

\section{F. PENUTUP}

F.1 Kesimpulan

Berdasarkan uraian dan pembahasan dari seluruh bab, maka dapat disimpulkan hasil penelitian ini berupa:

1. Penelitian ini telah berhasil membuat Aplikasi Peramalan Obat-Obatan dengan Metode Least Square.

2. Aplikasi peramalan obat-obatan dengan metode least square membantu proses perhitungan peramalan obat masa datang secara mudah. Dibandingkan perhitungan secara manual yang kemungkinan terdapat banyak kesalahan. Aplikasi ini memperkecil kesalahan dalam pengolahan data, sehingga informasi yang dihasilkan lebih akurat dan cepat.

3. Aplikasi ini juga memudahkan petugas dalam membuat laporan dan juga pengecekan stok obat.

\section{F.2 Saran}

Untuk penelitian selanjutnya, dapat digunakan metode peramalan yang lain untuk membandingkan kehandalan peramalan dari masing-masing metode peramalan.

\section{REFERENSI}

[1] Hariri, Fajar Rohman. "Metode Least Square Untuk Prediksi Penjualan Sari Kedelai Rosi." Jurnal SIMETRIS, Vol. 7 No. November 2016 ISSN: 2252-4983.

[2] Hariyanto, Bambang. "Sistem Manajemen Basisdata". Informatika, Bandung. 2004.

[3] It-jurnal. "Pengertian Flowchart". [online] available htts://www.itjurnal.com/pengertian-flowchart/, diakses 15 Februari 2018 
[4] Kustiyahningsih, Yeni dan Devie Rosa Anamisa. "Pemograman Basis Data Berbasis Web Menggunakan PHP \& MySQL". Graha Ilmu, Yogyakarta. 2011.

[5] Nugroho, Bunafit. "Database Relasional dengan $M y S Q L "$ ". CV. Andi, Yogyakarta. 2005.

[6] Nugroho, Djuzali Alimursid, Abuzar Asra. "Rumus-Rumus Statistik serta penerapannya". CV. Rajawali, Jakarta. 1985.

[7] Ramadhani, Cipta. "Dasar Algoritma dan Struktur Data dengan Bahasa Java". CV. Andi, Yogyakarta. 2015.

[8] Rambe, Muhammad Ihsan Fauzi. "Perancangan Aplikasi Peramalan Persediaan Obat-Obatan Menggunakan Metode Least Square (Studi Kasus: Apotik Mutiara Hati)." Pelita Informatika Budi Darma, 2014.

[9] Septiawan, Rachmad Budi dan Erna Zuni Astuti. "Perbandingan Metode Setengah Rata-Rata dan Metode Kuadrat Terkecil untuk Pendapatan Perusahaan di BLU UPTD Terminal Mangkang Semarang". Techno.COM, Vol. 15 No. 2 Mei 2016: 132-139.

[10] Sidik, Betha. "MySQL Untuk Pengguna Administrator dan Pengembangan Aplikasi Web". Informatika, Bandung. 2005.Sukamto dan M. Shalahuddin. "Rekayasa Perangkat Lunak Terstruktur dan Berorientasi Objek". Informatika, Bandung. 2013.

[11] Thidiweb. "Sejarah dan Perkembangan Bootstrap". [online] available https://thidiweb.com/pengertianbootstrap/, diakses 22 Februari 2018.

[12] Wirasta, Wendi dan Muhammad Luthfi Ashari. "Penerapan Least Square Method untuk Peramalan Penjualan di HijabStory Bandung". Program Studi Teknik Informatika, STMIK \& Ilmu Komputer LPKIA, Bandung, 2017. 